IRA-International Journal of Education \& Multidisciplinary Studies ISSN 2455-2526; Vol.04, Issue 03 (2016)

Pg. no. 423-437

Institute of Research Advances

http://research-advances.org/index.php/IJEMS

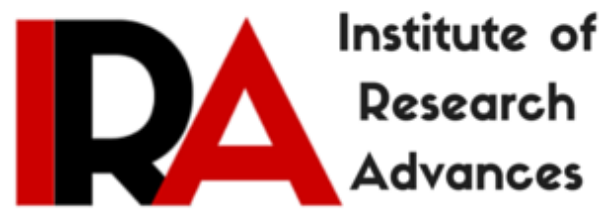

\title{
Student Centric Curriculum Design and Implementation - Challenges \& Opportunities in Business Management \& IT Education
}

\author{
Dr. P. S. Aithal
}

Srinivas Institute of Management Studies, Pandeshwar, Mangalore - 575 001, India.

Type of Review: Peer Reviewed.

DOI: http://dx.doi.org/10.21013/jems.v4.n3.p9

\section{How to cite this paper:}

Aithal, P. (2016). Student Centric Curriculum Design and Implementation - Challenges \& Opportunities in Business Management \& IT Education. IRA International Journal of Education and Multidisciplinary Studies (ISSN 2455-2526), 4(3), 423-437.

doi:http://dx.doi.org/10.21013/jems.v4.n3.p9

(C) Institute of Research Advances

(cc) EY-NC

This work is licensed under a Creative Commons Attribution-Non Commercial 4.0 International License subject to proper citation to the publication source of the work.

Disclaimer: The scholarly papers as reviewed and published by the Institute of Research Advances (IRA) are the views and opinions of their respective authors and are not the views or opinions of the IRA. The IRA disclaims of any harm or loss caused due to the published content to any party. 


\begin{abstract}
Student-centric curriculum design and implementation in higher education system are getting importance due to the reason of creating employable and skilled graduates who can take optimum decisions for industry problems and who can lead technocrat society. Even though student-centric curriculum is essential in all areas of higher education, it became essential in business management and information technology due to the fact that these areas are changing at a faster rate due to the enhanced competition in globalized business. In this paper, we have discussed the challenges and opportunities in curriculum planning, designing, and effective implementation in autonomous and affiliated business schools. We have discussed the possibility of designing industry oriented curriculum in business management and information technology, which contain both industry and research experience components. This student centric curriculum improvement model will take care of rapid growth of both the fields and the requirement of updating the curriculum with present developments. The opportunities and challenges of student centric curriculum design and developments in Business management subject and in Information technology subjects are discussed. The advantages, benefits, constraints, and disadvantages of such system are listed. Though the implementation of the new model is challenging, the advantages and the benefits outlay the disadvantages and the constraints.
\end{abstract}

Keywords: Curriculum design in Business Management, Curriculum design in Information Technology, New curriculum model in higher education, ABCD listing of student centric curriculum design.

\title{
1. Introduction
}

Higher education (HE) plays an important role in overall development of youths in a country by building their knowledge, skills, experience, and character and make them responsible contributor of nation building. Understanding existing knowledge and creating new knowledge are two essential and central aspects of higher education design and implementation model to solve problems in various fields of the society. Both these aspects must be taken as objectives while planning and designing curriculum in higher education system. By giving equal importance to the student's knowledge enhancement and student's involvement in new knowledge creation, higher education can reach its goal. Student centric curriculum design and implementation should focus on imparting the information in respective subjects effectively to enhance the knowledge of the students and utilizing these knowledge to progress further by creating new knowledge through research. Thus the two essential ingredients of student centric curriculum design and implementation are again innovation in knowledge imparting methodologies and involvement of students in research. Improvements in course definition, subject identification, information collection and presentation, choosing effective pedagogy for teaching \& learning, involving students in research through course design, and developing effective examination \& evaluation system are essential requirements in higher education curriculum design and implementation. Student-centric curriculum design and implementation in higher education system are getting importance due to the reason of creating employable and skilled graduates who can take optimum decisions for industry problems and who can lead technocrat society. Even though student-centric curriculum is essential in all areas of higher education, it became important and essential in business management and information technology due to the fact that these areas are changing at a faster rate due to the enhanced competition in globalized business [1-2].

Several studies on innovations and quality in higher education including Strategic Planning in Higher Education Institutions [3], Innovations and Best Practices can Transform Higher Education Institutions [4], quality in higher education [5-6], Internal Quality Assurance Cell and its Contribution [7], Enhancement of Graduate attributes in Higher Education Institutions through Stage Models [8], Quality Enhancement in Higher Education Institutions [9], Effective Leadership and Governance [10], Strategy 
Development and Deployment in Higher Education Institutions [11], Faculty Empowerment Strategies in Higher Education Institutions [12], Unique \& Successful Model in Integrated Development [13], Applying SWOC Analysis to an Institution of Higher Education [14], Techniques for Electric Energy Auditing in Education System [15], Societal Expectation And Institutional Accountability in Higher Education [16], Methods and Approaches for Employability Skill Generation in Higher Educational Institutions [17], Quality Enhancement in Higher Education Institutions through Best Practices in Library [18], Analysis of Academic Administrative System Implemented in Higher educational institution [19], Learning through Team Centric Exercise \& Key Point Pedagogy - An effective Learning Model for Slow Learners in Higher Education Training [20], Opportunities and Challenges for Private Universities [21], Innovations in Private Universities [22], Creating Innovators through setting up organizational Vision, Mission and Core Values : a Strategic Model in Higher Education [23], Comparative Study on MBA Programmes in Private \& Public Universities [24], Impact of On-line Education on Higher Education System [25], Innovations in Higher Education - A new model implemented in MCA degree programme [26], Environmental Consciousness in Higher Educational Institutions [27], Analysis of Choice Based Credit System in Higher Education [28], Innovations in Student Centric Learning - A Study of Top Business Schools [29], Innovations in Experimental Learning - A Study of World Top Business Schools [30], How to Increase Research Productivity in Higher Educational Institutions [31], Academic Support through Information System [32], and Quality Teaching and Learning as Practice Within Different Disciplinary Discourses [33], Innovative Education Model to realize Ideal Education System [34], ABCD analysis of Stage Model in Higher Education [35], ) Analysis of NAAC Accreditation System using ABCD framework [36], Application of ABCD Analysis Framework on Private University System [37], The Study of New National Institutional Ranking System using ABCD Framework [38], ABC Model of Research Productivity and Higher Educational Institutional Ranking [39], Smart Library Model for Future Generations [40], Green Education Concepts \& Strategies in Higher Education Model [41], Hitting Two Birds with One Stone : Srinivas University B.Com. Model in Corporate Auditing [42], Academic Support through Information System [43], Changing Approaches in Campus Placements - A new futuristic Model [44], Information Technology Innovations in Library Management [45], Teaching - Learning Process in Higher Education Institutions [46], Maintaining Teacher Quality in Higher Education Institutions [47], Student performance and Learning Outcomes in Higher Education Institutions [48], Catering Student Enrollment and Retaining Diversity in Higher Education Institutions [49], Student Evaluation and Reforms in Higher Education Institutions [50] are studied and results are published. In this paper, we have discussed the challenges and opportunities in curriculum planning, designing, and effective implementation in autonomous and affiliated business \& IT schools. We have discussed the possibility of designing industry oriented curriculum in business management and information technology, which contain both industry and research experience components. This curriculum model will take care of rapid growth of both the fields and the requirement of updating the curriculum with present developments. The opportunities and challenges of student centric curriculum design and developments in Business management subject and in Information technology subjects are discussed. The advantages, benefits, constraints, and disadvantages (ABCD) of such system are listed.

\section{Curriculum Design \& Development in HE}

Effectiveness in higher education involves innovation in course design, identification of subjects and curriculum for the course, information collection and presentation in these subjects as per the curriculum to the students, choosing effective pedagogy for teaching \& learning, involving students in research through course structure design, and developing effective examination \& evaluation system. Out of these stages in higher education system, the curriculum development and design for the subjects of a course plays central issue of higher education due to the fact that the success and effectiveness of all other steps of the course depends on it. 


\section{(1) Innovation in Course Design :}

Course design in higher education is a challenge for education experts. Apart from conventional courses in physical, chemical, biological sciences, engineering, medical and paramedical science, philosophical sciences like arts, commerce and business, and other areas, the present challenge is developing courses in multi-disciplinary and inter-disciplinary areas to make the higher education output more effective. By means of open mind and out of the box thinking, higher education experts can develop innovative courses which may promote new insight into the models and effectiveness of higher education in the society.

\section{(2) Identification of Subjects \& Curriculum for the Course :}

Once the courses are identified in different areas of science, engineering, social sciences, and humanities, with multi-disciplinary and inter-disciplinary approach, it is challenging to decide the duration of the courses, the number of subjects, nature of subjects, core and soft subjects and the qualification and experience of teachers have to be decided with special care to ensure the success of such new efforts in terms creating employable and skilled graduates who can take optimum decisions for industry problems and who can lead technocrat society.

\section{(3) Information Collection and Presentation in these Subjects to the Students as per the Curriculum :}

Once the course is designed, implementation of the course in higher education system involves teaching the subjects as per the curriculum in an effective manner by collecting the required information from books, online resources, experienced and knowledgeable teachers, industry experts. The collected information by teachers and students in the form of study materials, assignments should reach the learners as knowledge. Conversion of information of chosen subjects of the course into knowledge of learners through effective pedagogy is essential feature of higher education.

\section{(4) Choosing Effective Pedagogy for Teaching \& Learning :}

The effective methods of information imparting to the learners should be developed and used in higher education system depending on the nature of course and the subjects to be offered in the course. Choosing the effective pedagogy which is student centric and has assured success of enhancing knowledge is real challenge for higher education institutions and its teachers. Various pedagogies are currently used as well as under development using innovative teaching -learning models, information communication technology, multi-media technology and experimental learning methods.

\section{(5) Involving Students in Research through Course Structure Design :}

Apart from enhancing knowledge and skills in various chosen subjects of a course, the learners should involve in new knowledge creation in that and related subjects through their involvement in higher education system. This can happen by adding research components in curriculum. Through research projects by students and their effective evaluation, the higher educational institutions can develop research environment in higher education system. Thus the course design and implementation stage should focus the involvement of students along with faculty members to focus on new knowledge creation through research.

\section{(6) Developing Effective Examination \& Evaluation System :}

The higher education system reaches its goal if the objectives of enhancement of knowledge, skills, experience, and new knowledge creation in a course and subjects are realized. Developing effective examination and evaluation system include, continuous evaluation of student progress, innovations in examination and valuation systems including open book examinations, double valuation, transparency in evaluation process, avoiding year wasting of students through proper design of examination systems etc. The examination system should be designed to evaluate problem solving ability of the students through gained knowledge, skills and experience instead of checking their memorizing ability. 


\subsection{Curriculum as Central Issue :}

Curriculum development for a given course include identification of number of subjects as per the duration of the course, details of each subject including number of chapters, objective of each chapter, depth of each chapter, topics to be covered in each chapter, skills to be developed at the end of the study of each chapter, the experiments/projects to be completed in each chapter, the important references, the assignments to be completed after each chapter, etc. Since curriculum is the central issue of all courses in higher education system, special care must be given while developing new curriculum, and restructuring/revision of curriculum. Different methods of curriculum development include :

\section{(1) Teacher Based Curriculum :}

In teacher based curriculum the teacher designs the curriculum and decides the length and breadth of the subjects. The students just follow the teacher. The teacher only talks in the class, while the students exclusively listen. The students work alone during learning activities, and collaboration is not encouraged. In the classroom, students are quiet and the teacher maintains full control. In this system, the students learn to be independent and make their own decisions. They will not get opportunity to collaborate but work alone. As a result, their communication skills may suffer. Teacher-based curriculum model and its instruction make boring for the students due to the fact that they do not express themselves, ask questions to clear their ambiguity. Since teacher decides the objective of learning of the subject, the pedagogy, the evaluation methods, and the result of the study, this method is one-to-many system.

\section{(2) Subject Based Curriculum :}

Subject based curriculum is the conventional system where a panel of experts of universities decides course structure and designs the curriculum of each subjects. As per university system, the students have to compulsorily study these subjects to get the degree under the guidance of the teachers. The teachers are subject experts decides the teaching methodology and the evaluation system. There is no flexibility for choice of subjects for the students within a course and the teachers have to teach the concepts as per the curriculum developed by the university. This method is used in many university based higher education systems where the affiliated colleges simply follow the subject based curriculum without any freedom to divert or modify as per industry or society requirement.

\section{(3) Choice Based Curriculum :}

Choice based Curriculum system allows higher education model to transform from the traditional teacher oriented education to a student-centred education. In this mode, students choose the subjects and time duration by taking responsibility for their own education and can get benefit from all the available resources. In choice based curriculum, a student can take some subjects from one college and transfer the credits to some other college. A student can work part-time and study only few subjects for a given year and stretch his studies for longer duration according to his convenience. He has no compulsion to complete a degree programme in a fixed duration of say, three years. Choice based curriculum has the facility to transfer the credits from one institution to another and considers few credits earned in an industry within the curriculum. Students who have interest in creative and performing arts can also obtain credits from such subjects. Students are allowed to choose courses of inter-disciplinary nature with faculty advising, Choice based curriculum system can offer a very flexible open system for quality improvement in higher education. This system not only offers opportunities and avenues to learn core subjects but also exploring additional avenues of learning beyond the core subjects for holistic development of an individual and facilitate to bench mark Indian courses with best international academic practices. Innovative forward thinking autonomous colleges are showing interest to provide such systems.

\section{(4) Competency Based Curriculum :}

Competency-Based Curriculum is a drastic improvement in higher education model in which the students are allowed to personalize the learning by choosing the subjects, and also in assessment. In this system, students are asked to demonstrate their academic competence which includes their experience and 
assessment, to gain academic credit. In this model, a student need not necessarily have to take predetermined required and elective courses to be taught by assigned teachers. Instead, a student has to demonstrate a defined set of proficiencies and mastery of knowledge and content. In this system, unlike teacher based curriculum model, students and teachers interact equally and students learn important communicative and collaborative skills through group work and direct their own learning, ask questions and complete tasks independently. Competency-Based Curriculum supports students to study at their own pace, incorporates the process of prior learning assessment, and offers a logical framework for improving knowledge, skills and experience as per the demands of the industry to the extent decided by the respective institution [25]. In this model, students are more active and hence the classrooms are often busy, noisy and chaotic. The teachers struggle to manage all students' activities at once, which can be difficult when students are working on different stages of the same project. The teacher doesn't deliver instruction to all students at once and due to such repetitions some students may miss important facts. Also some students prefer to work alone, so for such students group work may become problematic.

\subsection{Pedagogy \& Evaluation as Subsidiary Issues :}

Pedagogy is the process of presenting content in the context of learning strategies that connect with a cognitive process. It now generally refers to creation of effective lesson plan for classroom instruction and online education. It is a teaching method comprises the principles and methods used for instruction to be implemented by teachers to achieve the desired learning in students. These strategies are determined partly on subject matter to be taught and partly by the nature of the learner. Pedagogy is the art (and science) of teaching. Effective teachers use an array of teaching strategies because there is no single, universal approach that suits all situations.

As per one research model [51], the pedagogies of higher education system are divided into five types as Intelligent, Distributed, Engaging, Agile \& Situated (IDEAS).

(1) Intelligent Pedagogies : Pedagogies which use technology to enhance the learning experience.

(2) Distributed Pedagogies : Pedagogies refers to shared or distributed ownership of different elements of the learner's journey by different stakeholders in the process like collaborative partnerships between institutions and industries.

(3) Engaging Pedagogies : Pedagogies which use student engagement in the learning process like active learning,

(4) Agile Pedagogies : It refers to flexibility and responsiveness to learners' needs. Some of the practices are Facilitating personalisation and flexibility, Recognising prior learning, Experienced learners groups, Internationalization of student groups etc.

(5) Situated Pedagogies : It refers to the real-world relevance of the curriculum and the contextualization of the learning process in terms of learners' personal or professional goals like discussion on recent hot issues in the business.

\section{Innovations in Business Management \& IT Educations}

Even though student-centric curriculum is essential in all areas of higher education, it became essential in business management and information technology due to the fact that these areas are changing at a faster rate due to the enhanced competition in globalized business. Thus innovations in curriculum planning, designing, and effective implementation are very important in autonomous and affiliated business \& IT schools.

\section{(i) Introducing Innovations and Best Practices :}

Higher education has become competitive in terms of both quantity and quality that it delivers the knowledge. Student centric focus is gradually shifting to student friendly approaches, and innovations and best practices are adapted to add value and get more mileage in the knowledge delivery. Changes in culture, aspiration and levels of skills required in securing employment for students and cost of providing the service, force higher education institutions today to rework on their educational models and add value at each and every aspects in their service. Any changes in the quality of higher education by improving 
either course design and curriculum, delivery methods, technology support, infrastructure facilities, pedagogy, evaluation system, placement methods etc. are considered as innovations in higher education. Time tested innovations are implemented in the form of best practices when they are worked out into a system which is durable and endurable. Innovations and best practices and their affect on quality of knowledge, skills, smartness, and experience make higher education attractive. Innovations in business management education and information technology education became very important after globalization due to their inter-dependency on providing quality product and services to the society.

\section{(ii) Expanding to new areas :}

As time progresses, due to increased availability of higher education opportunity to many people in the world, more and more people are involved in research and development in all areas of natural science and philosophical science. This leads to development of new areas of information and knowledge. Such new areas of interest generate further opportunities both for further studies through research and development and create job opportunities. For example, business analytics, and e-business are new integrated emerging areas of business management and information technology.

\section{(iii) Following new Models :}

As research progress in higher education, new models which interconnect various affecting variables for a given problem of subjects are developed. These models may be exhaustive and comprehensive so that they may represent and explain the system more appropriately. This allows such models to become more attractive in solving problems and acceptable from every business practitioner. Thus new models developed in business management area may take care of new developments in the business environment and may become popular.

(iv) Using new Analysis Frameworks :

Changes in higher education and research are not only due to emergence of new areas, new models, new methods, but also due to changes in analysis methods. Due to continuous research in higher education systems, new methods and frameworks are developed or under development in both business management and information technology subjects to study the effectiveness of the system, concept, ideas, strategy, technology, and even material for a given applications etc. Various analysis methods like SWOT framework [14, 52], ABCD framework [53-57], and ideal system concepts [58-64] are recently developed and used as analysis frameworks both in business management and information technology subject areas.

\section{(v) Measuring New Way of Success :}

Developing metric system to measure academic output in higher education system is challenging and based on such metric only, the faculty members and the higher education institutions should seriously look into their contribution. The performance of higher educational institution should not be measured based on the quality input of admitted students, the infrastructure provided, the academic result achieved, the international exposure, the amount of fee the institution is charging on students and the placement performance. Institutional productivity and performance should not be measured based on number of industry linkage, number of Management Development Programmes (MDP) \& Faculty Development Programmes (FDP) it conducted, the amount of money through consultation and the number and amount of funding it received through projects, but the performance of higher education institution should be based on the 'New Knowledge' it has created. According to newly developed ABC model of higher educational research performance, the research performance can be calculated using its annual research output by taking into account on number of articles published in referred journals (A), number of books published (B) and number of Chapters in edited book or number of business cases published in Journals (C). As per ABC model, one can determine the institutional annual research index $\alpha=[(2 \mathrm{~A}+5 \mathrm{~B}+\mathrm{C}) / \mathrm{F})]$ or institutional weighted annual research index $\beta=[2 \mathrm{~A}+5 \mathrm{~B}+\mathrm{C}) / 8 \mathrm{~F}]$, where $\mathrm{F}$ is fulltime faculty members of the organization [31], [39], [65-66]. 


\section{Student-centric approach in Business Management Curriculum Design}

(1) Adding New Areas of Studies : Many new emerging areas can be added to business management curriculum which include : Business analytics and intelligence, E-business \& M-business, Business Process Management, Knowledge management, Digital Marketing, Green Business, Technology Management \& Commercialization of new Products and services, Financial Risk Management, Decision Science, Supply Chain Management, and Social Entrepreneurship etc. Mastering new emerging areas will add competitive edge to the students.

(2) Removal of Obsolete Concepts : Many obsolete concepts should be removed in business management curriculum which include : Organizational theories of before $20^{\text {th }}$ century, People management theories before $20^{\text {th }}$ century, Marketing strategy during pre-digital era, Production management without automation, Old concepts in financial management, Various trial and error methods before developing quantitative techniques, Obsolete concepts in various functional areas of business management.

(3) De-focusing Old Relevant Concepts : Many business concepts which are irrelevant in present day society due to changes in technology, changes in people perception, changes in business models, changes in industry requirement etc. should be de-focussed while designing business management curriculum.

\section{(4) Exploring Multi-disciplinary Areas :}

Many multi-disciplinary areas which integrate business management with other field of studies like inventory management, management information systems, management economics, management accounting, statistical management, operations research and quantitative techniques, web-business, digital marketing, energy management, health \& health services management etc. should be considered while designing innovative higher education business management curriculum.

\section{(5) Evaluating New Technologies :}

Business Management curriculum has to be upgraded as per changes in supporting technologies which controls business processes. Advent of information technology and internet changed the business model from brick and mortar to click and mortar. Similarly, presently, nanotechnology is emerging as multidisciplinary new frontier of science and technology produces many innovative products and services to solve present and future needs of the society. Other technologies like bio-technology, Medical technology, Space technologies, renewable energy technologies are creating huge business opportunities so that they have to be included in business management curriculum.

\section{Student-centric approach in IT Curriculum Design}

\section{(1) Adding New Areas of Studies}

Many new emerging areas can be added to IT curriculum in order to make it industry friendly which include : Enterprise computing, Artificial intelligence, Image processing, Cloud computing, Industrial automation, New operating systems, Open source platforms, Virtualization, Mobile/wireless and optical communication, Data \& Information management, Bio-informatics, etc.

\section{(2) Removal of Obsolete Concepts}

Many obsolete concepts should be removed in business management curriculum which include some of the computer languages like Basic, Forton, Cobol, etc., Operating systems like DOS, analog communication systems etc.

\section{(3) De-focusing Old Relevant Concepts}

Many concepts which are irrelevant in present day society due to changes in technology, changes in people perception, changes in business models, changes in industry requirements, globalization etc. 
should be de-focussed while designing Information technology curriculum. This include some of the computer languages like $\mathrm{C}, \mathrm{C}++$, etc., Operating systems like windows, communication systems without security, Old wireless communication technologies including $2 \mathrm{G}$ etc. should be given less importance.

\section{(4) Exploring Multi-disciplinary Areas :}

Computer science and IT curriculum has to be upgraded as per changes in supporting technologies which controls various computing and communicating processes. Changes in business models in the society and opportunities to solve basic problems in the society like food, potable water, renewable energy, and decease free health, supports invention of new technologies like nanotechnology which can be integrated with existing technologies as hybrid technologies used to solve basic problems in the society and to provide comfortability for human life in the society. Such emerging technologies and business opportunities can be included in future IT curriculum.

\section{Opportunities \& Challenges in Business Management \& IT Curriculum Design}

\section{(i) Developing new Pedagogy:}

- Developing new pedagogy based on technology.

- Developing new pedagogy based on industry requirement.

- Developing new pedagogy based on research components added to the curriculum.

- Developing new pedagogy based on international collaboration components.

- Developing new pedagogy based on new multi-disciplinary and inter-disciplinary. subjects added to the curriculum.

- Developing new pedagogy based on institutional collaborations.

- Developing new pedagogy based on students requirements.

(ii) Introducing new Assessment Methods :

- Introducing continuous assessment methods instead of annual or semester end exams.

- Introducing open book exams and quick announcement of result.

- Multiple choice components and online exams.

- Introducing compulsory marks on research publications in conferences and journals.

- Introducing compulsory marks on business case development and publication in case journals.

- Introducing competency based assessment and evaluation system.

- Allotting marks for earning placement offer through tough interviews by reputed companies.

- Allotting marks for civil services or other competitive exams to secure jobs at executive levels of public sector organizations.

(iii) Adding Experimental Components :

- Adding compulsory industry projects in each semester.

- Adding simulations and experimental learning components in various functional areas.

- Accepting on-job training for credit in competency based assessment model.

- Encouraging earn while learn model to the students at higher education level to acquire experimental experience.

- Arranging industrial visits at national and international level relevant in specialized areas.

- Introducing documentary videos, factory production videos and training students in big data handling and analysis.

(iv) Arranging Placement through Innovative Placement Model :

- Introducing student centred bottom-up online method of placement model. 
- Encouraging students to develop case studies of their dream companies and suggest business development opportunities to them to secure placement offers.

- Encouraging and training the students to start online business along with their effort on securing dream placements.

\section{ABCD Listing of Curriculum Updating}

\section{(1) Advantages :}

- Student centric curriculum supports students to focus on studies to enhance their knowledge, skills and experience in chosen subject.

- Curriculum updating removes obsolete items in the subjects so that students have to study only useful information and skills in higher education.

- Introducing new curriculum creates opportunity to faculty members to learn new things which are latest developments in that subject through organizational support.

- Faculty members will also update their knowledge and skills for effective training of students.

- Industries get an opportunity to participate in curriculum design and development process with the institutions.

\section{(2) Benefits :}

- Student Centred curriculum supports students to get better job and prosper in that field due to enhanced knowledge, skills and experience in chosen subject.

- Students need not study obsolete part of the syllabus and can save their time.

- Organization can enhance its brand image by means of its innovative practice of adopting student centric curriculum.

- Faculty members will get an opportunity to upgrade their knowledge and skills to teach current requirements in industries through their organizational financial support.

- Industries get better knowledgeable employees which will decrease expenditure of training at initial stage.

\section{(3) Constraints :}

- Constant updating the curriculum as per industry requirement is challenging in organizations.

- Collecting information in a given subject as per new curriculum is difficult due to limited availability.

- Organizational constraints like providing infrastructure like advanced laboratories, providing additional books in library, training the faculty members for new curriculum etc

- Students also have to do hard work and spend more time for understanding for new curriculum.

(4) Disadvantages :

- Faculty updating continuously as per changes in the curriculum is a difficult process.

- Organizational constraints like providing infrastructure like advanced laboratories, providing additional books in library, training the faculty members for new curriculum etc have additional cost. Frequent changes in curriculum creates extra financial burden on organization.

- Some students may find it difficult due to introduction of advanced industry oriented syllabus and its update periodically.

\section{Conclusion}

The challenges and opportunities in curriculum planning, designing, and effective implementation in autonomous and affiliated business \& IT schools for continuous up-gradation is discussed. Based on the 
discussion, the possibility of designing industry oriented effective curriculum in business management and information technology, which contain both industry and research experience components are identified. This curriculum model will take care of rapid growth of both business management and information technology fields and the requirement of updating the curriculum with present developments. Though the implementation of the new model is challenging, the advantages and the benefits outlay the disadvantages and the constraints.

\section{References}

[1] Hill, Y., Lomas, L., \& MacGregor, J. (2003). Students perceptions of quality in higher education. Quality Assurance in Education, 11(1), 15-20.

[2] Joseph, M., Yakhou, M., \& Stone, G. (2005). An educational institutions quest for service quality: customers" perspective. Quality Assurance in Education, 13(1), 66-82.

[3] Srinivas Rao, A., Suresh Kumar P. M., \& Aithal P. S. (2015). Strategic Planning in Higher Education Institutions : A Case Study of SIMS - VISION 2025. International Journal of Educational Science and Research, 5(2), 29-42.

[4] Aithal, P. S., Srinivas Rao, A., \& Suresh Kumar, P. M. (2015). How Innovations and Best Practices can Transform Higher Education Institutions : A case study of SIMS. International Journal of Management (IJM), 6(2), 83-98.

[5] Gopal, K. K., Abdul Malek Bin A., Tambi, \& William Wallace, (1999). A comparative study of quality practices in higher education institutions in the US and Malaysia. Total Quality Management, 10(3), 357-371.

[6] Mohammad, S. O. (1996). Quality in higher education-a survey. Total Quality Management, 7(2), $161-172$.

[7] Aithal, P.S. (2015). Internal Quality Assurance Cell and its Contribution to Quality Improvement in Higher Education Institutions : A Case of SIMS. GE International Journal of Management Research (IJMR), 3(5), 70-83.

[8] Aithal, P. S., \& Suresh Kumar, P. M. (2015). Enhancement of Graduate attributes in Higher Education Institutions through Stage Models. IMPACT: International Journal of Research in Business Management, 3(3), 121-130.

[9] Aithal, P. S., Srinivas Rao, A., \& Suresh Kumar, P. M. (2015). Quality Enhancement in Higher Education Institutions : A case study of SIMS. International Journal of Multidisciplinary Research and Development, 2(5), 18-31.

[10] Aithal, P. S. (2015). How an Effective Leadership and Governance Supports to Achieve Institutional Vision, Mission, and Objectives. International Journal of Multidisciplinary Research and Development, 2(5), 154-161.

[11] Aithal, P. S. (2015). Strategy Development and Deployment in Higher Education Institutions. Elixir International Journal, 84, 33594-33597.

[12] Aithal, P. S. (2015). Faculty Empowerment Strategies in Higher Education Institutions. International Journal of Management, IT and Engineering (IJMIE), 5(7), 108-115.

[13] Aithal, P. S. (2015). MBA++ as a Unique \& Successful Model in Integrated Development of Business Executives. International Journal of Management, IT and Engineering (IJMIE), 5(7), 124-133.

[14] Aithal, P. S., \& Suresh Kumar, P. M. (2015). Applying SWOC Analysis to an Institution of Higher Education. International Journal of Management, IT and Engineering (IJMIE), 5(7), 231-247. 
[15] Aithal, P. S., \& Sridhar Acharya, P. (2015). Techniques for Electric Energy Auditing in Education System. International Journal of Management, IT and Engineering (IJMIE), 5(7), 318-325.

[16] Aithal, P. S., Suresh Kumar, P. M., \& Deekshitha, (2015). Societal Expectation And Institutional Accountability in Higher Education. International Journal of Management, IT and Engineering (IJMIE), 5(7), 361-373.

[17] Aithal, P. S., Suresh Kumar, P. M., \& Pavithra, K. (2015). Methods and Approaches for Employability Skill Generation in Higher Educational Institutions. International Journal of Management, IT and Engineering (IJMIE), 5(7), 390-410.

[18] Aithal, P. S., \& Harischandra, P. (2015). Quality Enhancement in Higher Education Institutions through Best Practices in Library: A Case of SIMS. International Journal of Management, IT and Engineering (IJMIE), 5(7), 489-505.

[19] Reshma, Shailashree, V. T., Sridhar Acharya, P., \& Aithal, P. S. (2015). Analysis of Academic Administrative System Implemented at SIMS. International Journal of Management, IT and Engineering (IJMIE), 5(7), 771-787.

[20] Pradeep, M. D., \& Aithal, P. S. (2015). Learning through Team Centric Exercise \& Key Point Pedagogy - An effective Learning Model for Slow Learners in Higher Education Training. International Journal of Multidisciplinary Research \& Development, 2(9), 265-270.

[21] Aithal, P. S., \& Suresh Kumar, P. M. (2016). Opportunities and Challenges for Private Universities in India. International Journal of Management, IT and Engineering (IJMIE), 6(1), 88-113.

[22] Aithal, P. S., \& Suresh Kumar, P. M. (2016). Innovations in Private Universities : A Case of Srinivas University. International Journal of Management, IT and Engineering (IJMIE), 6(1), 250-264.

[23] Aithal, P. S. (2016). Creating Innovators through setting up organizational Vision, Mission and Core Values : a Strategic Model in Higher Education. International Journal of Management, IT and Engineering (IJMIE), 6(1), 310-324.

[24] Aithal, P. S. (2015). Comparative Study on MBA Programmes in Private \& Public Universities - A case study of MBA programme plan of Srinivas University. International Journal of Management Sciences and Business Research (IJMSBR), 4(12), 106-122.

[25] Aithal, P. S., \& Shubhrajyotsna Aithal, (2016). Impact of On-line Education on Higher Education System, International Journal of Engineering Research and Modern Education (IJERME), 1(1), 225235.

[26] Aithal, P. S., \& Jeevan, P. (2016). Innovations in Higher Education - A new model implemented in MCA degree programme of Srinivas University. International Journal of Scientific Research and Modern Education (IJSRME), 1(1), 275-289.

[27] Sridhar Acharya, P., \& Aithal, P. S. (2016). Environmental Consciousness in Higher Educational Institutions : A case of SIMS. International Journal of Current Research and Modern Education (IJCRME), 1(1), 273-284.

[28] Aithal, P. S., \& Suresh Kumar, P. M. (2016). Analysis of Choice Based Credit System in Higher Education. International Journal of Engineering Research and Modern Education (IJERME), 1(1), 278284.

[29] Aithal, P. S. (2016). Innovations in Student Centric Learning - A Study of Top Business Schools in India. International Journal of Engineering Research and Modern Education (IJERME), 1(1), 298-306.

[30] Aithal, P. S. (2016). Innovations in Experimental Learning - A Study of World Top Business Schools. International Journal of Scientific Research and Modern Education (IJSRME), 1(1), 360-375. 
[31] Aithal, P. S. (2016). How to Increase Research Productivity in Higher Educational Institutions SIMS Model. International Journal of Scientific Research and Modern Education (IJSRME), 1(1), 447458.

[32] Aithal. P. S., \& Suresh Kumar, P. M. (2016). Academic Support through Information System : Srinivas Integrated Model. International Journal of Scientific Research and Modern Education (IJSRME), 1(1), 376-384.

[33] Line Wittek, Laurence Habib, Laurence Habib, (2013). Quality Teaching and Learning as Practice Within Different Disciplinary Discourses. International Journal of Teaching and Learning in Higher Education, 25(3), 275-287.

[34] Aithal, P. S., \& Shubhrajyotsna Aithal, (2015). An Innovative Education Model to realize Ideal Education System. International Journal of Scientific Research and Management (IJSRM), 3(3), 24642469.

[35] Aithal, P. S., Shailashree, V. T., \& Suresh Kumar P.M. (2016). ABCD analysis of Stage Model in Higher Education. International Journal of Management, IT and Engineering (IJMIE), 6(1), 11-24.

[36] Aithal, P. S., Shailashree V.T., \& Suresh Kumar, P.M. (2016). Analysis of NAAC Accreditation System using ABCD framework. International Journal of Management, IT and Engineering (IJMIE), 6(1), 30-44.

[37] Aithal, P. S., Shailashree, V. T., \& Suresh Kumar, P. M. (2016). Application of ABCD Analysis Framework on Private University System in India. International Journal of Management Sciences and Business Research (IJMSBR), 5(4), 159-170.

[38] Aithal, P. S., Shailashree, V. T., \& Suresh Kumar, P.M. (2016). The Study of New National Institutional Ranking System using ABCD Framework, International Journal of Current Research and Modern Education (IJCRME), I(1), 389-402.

[39] Aithal, P. S., \& Suresh Kumar, P. M., (2016). ABC Model of Research Productivity and Higher Educational Institutional Ranking, Proceedings of National conference on Curriculum Design and Development for Student centric Learning, Mangalore, India, 11-22, ISBN 978-81-929306-9-5.

[40] Aithal, P. S. (2016). Smart Library Model for Future Generations. International Journal of Engineering Research and Modern Education (IJERME), 1(1), 693-703.

[41] Prithi, R., \& Aithal, P. S., (2016) Green Education Concepts \& Strategies in Higher Education Model. International Journal of Scientific Research and Modern Education (IJSRME), I(1), 793-802.

[42] Aithal, P. S., \& Sonia, D. N. (2016). Hitting Two Birds with One Stone : Srinivas University B.Com. Model in Corporate Auditing. International Journal of Scientific Research and Modern Education (IJSRME), I(1), 853-869.

[43] Aithal, P. S., \& Suresh Kumar, P. M., (2016) Academic Support through Information System : Srinivas Integrated Model, International Journal of Scientific Research and Modern Education (IJSRME), Vol. I, Issue I, pp.376-384.

[44] Varun, S., \& Aithal P. S. (2016). Changing Approaches in Campus Placements - A new futuristic Model, International Journal of Scientific Research and Modern Education (IJSRME), 1(1), 766-776.

[45] Harischandra, P., Shylesh, S., Aithal, P. S. (2016). Information Technology Innovations in Library Management: A Case of SIMS. International Journal of Current Research and Modern Education (IJCRME), I(1),. 657-676.

[46] Aithal, P. S., \& Suresh Kumar, P. M. (2016). Teaching - Learning Process in Higher Education Institutions, International Journal of Multidisciplinary Research and Modern Education (IJMRME), 2(1), 662-676. 
[47] Aithal, P. S., Suresh Kumar, P. M., (2016). Maintaining Teacher Quality in Higher Education Institutions. International Journal of Current Research and Modern Education (IJCRME), I(1), 701-711.

[48] Aithal, P. S., \& Suresh Kumar, P.M. (2016). Student performance and Learning Outcomes in Higher Education Institutions. International Journal of Scientific Research and Modern Education (IJSRME), 1(1), 674-684.

[49] Aithal, P. S., \& Suresh Kumar, P.M., (2016). Catering Student Enrollment and Retaining Diversity in Higher Education Institutions. International Journal of Engineering Research and Modern Education (IJERME), 1(1), 565-577.

[50] Aithal, P. S., \& Suresh Kumar, P. M. (2016). Student Evaluation and Reforms in Higher Education Institutions. International Journal of Multidisciplinary Research and Modern Education (IJMRME), 2(1), 652-661.

[51] Witthaus, G. (2016). Next Generation Pedagogy: IDEAS for Online and Blended Higher Education, Downloaded from http://openaccess.uoc.edu/webapps/o2/bitstream/10609/51441/1/ Next_Generation_ Pedagogy.pdf. 23-27.

[52] Marilyn M. H., \& Judy N., (2010). Exploring SWOT analysis - where are we now?: A review of academic research from the last decade. Journal of Strategy and Management, 3(3), 215-251.

[53] Sridhar Acharya, P., \& Aithal, P. S. (2016). Concepts of Ideal Electric Energy System for production, distribution and utilization. International Journal of Management, IT and Engineering (IJMIE), 6(1), 367-379.

[54] Padmanabha Shenoy, \& Aithal, P. S. (2016). A Study on History of Paper and possible Paper Free World. International Journal of Management, IT and Engineering (IJMIE), 6(1), 337-355.

[55] Aithal P. S., Shailashree V. T., Suresh Kumar P. M., A New ABCD Technique to Analyze Business Models \& Concepts, International Journal of Management, IT and Engineering (IJMIE), Vol. 5, Issue 4, pp. 409 - 423, April 2015.

[56] Aithal, P. S., Shailashree, V. T., \& Suresh Kumar, P. M. (2015). Application of ABCD Analysis Model for Black Ocean Strategy. International Journal of Applied Research (IJAR), 1(10), 331-337.

[57] Aithal, P. S., (2016). Study on ABCD Analysis Technique for Business Models, Business strategies, Operating Concepts \& Business Systems. International Journal in Management and Social Science, 4(1), 98-115.

[58] Aithal, P. S., \& Shubhrajyotsna Aithal, (2015). Ideal Technology Concept \& its Realization Opportunity using Nanotechnology. International Journal of Application or Innovation in Engineering \& Management (IJAIEM), 4(2), 153 - 164.

[59] Aithal, P. S., (2015). Concept of Ideal Business \& Its Realization Using E-Business Model. International Journal of Science and Research (IJSR), 4(3), 1267-1274.

[60] Aithal, P. S., (2015). Mobile Business as an Optimum Model for Ideal Business. International Journal of Management, IT and Engineering (IJMIE), 5(7), 146-159.

[61] Aithal, P. S., \& Shubhrajyotsna Aithal, (2014). Ideal education system and its realization through online education model using mobile devices. Proceedings of IISRO Multi Conference 2014, Bangkok, 140-146. ISBN No. 978-81-927104-33-13.

[62] Aithal, P. S. (2016). The concept of Ideal Strategy \& its realization using White Ocean Mixed Strategy, International Journal of Management Sciences and Business Research (IJMSBR), 5(4), 171179. 
[63] Aithal, P. S. (2016). Concept of Ideal Banking and Realization of it using Ubiquitous Banking, Proceedings of National Conference on Changing Perspectives of Management, IT, and Social Sciences in Contemporary Environment, Manegma 2016, India. 13-24. ISBN 978-93-5265-6523.

[64] Aithal, P.S., \& Vaikuth Pai, T., (2016). Concept of Ideal Software and its Realization Scenarios. International Journal of Scientific Research and Modern Education (IJSRME), I(I), 826-837.

[65] Aithal, P.S. (2016). Study of Research Productivity in World Top Business Schools, International Journal of Engineering Research and Modern Education (IJERME), I(1), 629-644.

[66] Aithal, P. S. (2016). Study of Annual Research Productivity in Indian Top Business Schools. International Journal of Scientific Research and Modern Education (IJSRME), I(1), 402-414. 